\title{
Independent auditing effect on investment decisions of institutional investors
}

\author{
Atila Karkacier ${ }^{a, 1}$ and Fatih Coşkun Ertaş ${ }^{a}$ \\ ${ }^{a}$ Gażosmanpaşa University, Tokat, Turkey
}

\begin{abstract}
A bstract: It is very important for investors to get accurate and reliable information so that they can earn large amounts of revenue from decisions they make. However, in recent years, population growth, the expansion of the economy and the complexity of economic life have reduced the credi bility of the information presented. The need for accurate and reliable information leads to requests for accounting and auditing activities. The independent audit, which increases the credibility of the information provided by the company and the reports it prepares, is also important in terms of investors, lenders and business owners. The aim of this study is to determine whether institutional investors are influenced by independent audit practices and the results of their investment decisions, and if so, how effective they are In this study, firstly information about institutional investors is given and the factors affecting investment decisions are mentioned. Later, information on auditing was included. In the last part of the study, a questionnaire was applied to the managers of institutional investors consisting of banks, brokerage houses, investment trusts and portfolio management companies registered in the Turkish Capital Markets Association (TCMA) to investigate whether any independent auditing practices and results had any effect on investment decisions of institutional investors. As a result of the analyzes made, it has been determined that institutional investors consider the independent audit report and its results together with the investment decisions of the independent audit financial tables and have effects on their decisions.
\end{abstract}

K eywords: Institutional Investor, Investment Decisions, Independent Audit

\footnotetext{
${ }^{1}$ Correspondence address: Atila Karkacier, Gaziosmanpaşa University, Research Assistant at GOÜ Faculty of Business/Accounting \& Finance Division. E-mail: atila.karkacier@gop.edu.tr
} 
JEL codes: G11, M41, M42

\section{Introduction}

It is a big deal in terms of the fact that the financial statements prepared by the companies show reliable and timely information. Macroeconomic indicators and the financial position of the investor are the determinants of investors' decisions. Investors, in particular, decide whether to invest in the shares of the enterprises by examining the financial position and results of operations (Coşkun et al., 2013: 11). Instead of small investors, institutional investors are called specialized financial institutions that manage savings in a collective way in terms of the level of risk, return and target of investment.

The presence of new financial instruments in the economy and the feeling of the effects of technological developments on the economy increase the demand for reliable information. In particular, the reliability of the information that they obtain from investing in investments for investors is of utmost importance Investors should investigate that the information disclosed in the name of the decision will be as reliable as possible. In verifying the reliability of the information disclosed, it is a common practice to check this information by an independent person. Integrity, correctness and impartiality must be audited and verified in order for information to be accepted as reliable information for decision-making (Erdoğan, 2002: 62-63).

At this point, appropriate and sufficient independent audit evidence to provide a reasonable assurance of conformity and accuracy between the financial statements and other financial information formed as a result of the economic activities of an entity and previously established criteria and the application of appropriate independent audit techniques recommended in the independent audit standards, And an independent audit, whose results are linked to the report, has emerged (Kardeş - Selimoğlu et al., 2011: 5).

The main purpose of the research is to demonstrate whether the institutional investor has an independent audit on the investment decisions and the effect of the results. The study also explores the perception differences between independent brokerage firms, portfolio management companies, investment partnerships, and bank, which are among the institutional investor types, to consider independent control when making investment decisions. However, it is important to investigate the contribution of the literature to the measurement and evaluation of the interaction between independent audit results and practices and institutional investors who are making investment decisions. 
This study consists of a total of four sections except for the introduction and conclusion section. In the first part of the study, information about institutional investors is given. In the second part, independent audit is examined. In the third chapter, similar studies are introduced in the literature review. In the fourth part, the scope of the research, the method applied in the research, the analysis of the research data, findings and interpretations are given. Finally, in the light of the findings obtained from the survey, the resul ts were evaluated and suggested.

\section{F actors affecting institutional investors and investment decisions}

Investors are classified as institutional investors and individual investors according to the party to which the funds are directed. Individual investors often do not have the opportunity to follow the market constantly, act according to their developments and manage their portfolios professionally when they do not have the necessary technical equipment and sufficient expertise. Portfolios created with individual savings that do not reach sufficient size are often referred to as risky portfolios. It is also not possible for individual investors to be distracted because they can invest only a few borrowing shares or shares with limited savings they have As such, institutional investors have been formed in capital markets as collective investment institutions (Akın and Ece, 2011: 12).

Institutional investors who take the role of collecting the fund surplus that individuals make positively between the income they earn and the expenditures they incur and the large amount of these funds being evaluated within the legal boundaries try to operate in order to diversify the funds they collect through individual investors in terms of investor groups and to provide the highest return (Usul and Kocabiyik, 2010: 65). Institutional investors include mutual funds, private pension funds, investment trusts, brokerage houses, portfolio management companies, insurance companies, social security institutions and banks.

Institutional investors are the most important component of the demand trend of capital markets in developed countries because they eval uate the high level funds they obtain from various sources by channeling them to capital market instruments according to expert staff and return expectations and risk expectations (Zor and Aslanoglu, 2005: 185). Institutional investors can play an important role in the development of financial markets as well as contribute to overall domestic economic growth. Institutional investors dynamically influence both financial sector growth and economic growth (Harichandra and Thangavelu, 2004: 7-8).

However, institutional investors are generally considered to have a positive effect on share prices of the companies they invest in. This effect is achieved through 
different mechanisms. Institutional investors reduce information asymmetry between the firm and other investors. It improves the corporate governance of the companies. It also contributes to the liquidity of companies (Huyghebaert and Hulle, 2004: 690).

Investment decisions are one of the most important tasks and responsibilities of the finance function. In order to be able to make a positive decision about any investment topic in terms of business management, the profit to be provided by this investment should meet the cost that it will cause. However, investment should provide profit for the entrepreneur (Babuşcu and Hazar, 2007: 109). Factors affecting investment decisions can be classified as economic factors, political factors, information sources, socio-cultural factors and psychological factors.

\section{Independent audit}

In recent years, with the increase of economic activities, the reliability of the information provided by the enterprises due to the more complicated transactions, the surplus of the data and the approaches of the informants have been questioned more and the needs of the information users have become more reliable and widespread (Kardeş-Selimoglu et al., 2011: 2). Relevant and reliable information needs have led to accounting and auditing services. For example; an investor who wants to invest money in stock, a bank that has to give credit to the business, a public institution that is trying to get the right to make a healthy decision definitely needs reliable information (Ataman et al., 2001: 13).

In the business world, it is very difficult for information users to get the information they desire first hand. When knowledge is obtained from others, it is more likely that it is intentionally or otherwise misrepresented. When there is a conflict of interest between the information clai mant and the information provider, there is a risk that the information presented is misleading. Here are three things that can be done against the riskier. The first is to obtain and control the desired information on its own; second, to rely on the other side to enter into a risk; and the third is to resort to independent audit opinion (Kardeş-Selimoğlu et al., 2011: 2).

Independent auditing is the audit and compliance and performance audits of the financial statements of the enterprises by an auditor or auditor who, within the scope of an audit agreement, provide the professional audit service to the clients, who work on their behalf as a self-employed person or perform their duties as an auditor. Financial audit is the main objective of independent audit (Uzun, 2007: 4).

An audit is the process of providing assurance about the accuracy of the information taking place in the financial statements prepared in accordance with 
generally accepted acounting principles or other rules. The responsibility of the financial statements of a company belongs to the management of the company (Soltani, 2007: 4).

Based on these definitions, we can list the main features of the audit as follows (Güçlü, 2008: 1-2):

- Auditing is a process: It covers a certain period.

- Interested in economic activities and other events.

- Auditing has predetermined criteria.

- The audit must be impartial.

- The most basic principle of auditing is to collect evidence and evaluate them

- Auditing is obliged to report the results to the addressees.

Auditing enhances the reliability of information provided to investors, business owners, lenders and other users. In short, the task of the auditor is to detect mistakes and deceptions. The results of the audit practices appear in the audit report. Today, the primary goal of auditing is to approve the correctness of financial statements. Auditing not only reduces the cost of exchanging information between managers and shareholders as an important part of the capital market framework, but also points to a marketplace where information is trustworthy (Salehi, 2010: 70-82).

\section{L iterature review}

In general, independent audit and its qual ity with the independent audit report and the internal audit report are found in a number of literature studies examining the effect on investment and lending decisions as well as the effect of investor confidence and stock return. There are studies in the literature that show that auditor opinion is important and should be taken into account when trying to measure the impact of auditor opinions on investment decisions and credit approvals (Gómez-Guillamón, 2003; Holt and DeZoort, 2009; Lai, 2009; Mansi, Maxwell and Miller, 2004; Ruiz-Barbadillo et al., 2004; Salehi, 2010). As a result, it is stated that these studies take into account the auditor's opinion on investment decisions and credit approval. Companies that have significant investment opportunities have been audited by 5 maj or audit companies; it is also emphasized that the audit report is an important parameter when making investment decisions.

On the other hand, there are also some studies in the literature that are opposite of the results above. Studies in which the audit reports and audit opinions have no effect on the decision makers are also included in the literature (Kabajeh et al., 
2012; Martinez et al., 2004; Ogneva \& Subramanyam, 2007; Tahinakis et al., 2010; Moradi et al., 2011; Anvarkhatibi et al., 2012). The results of the studies show that both company managers and lenders think that the auditor's report is not completely unbiased, inadequate and inappropriate when making decisions. In addition, lenders declare that these reports do not make a positive contribution to their credit decisions. In addition, the findings of the studies show that conditional audit reports do not have the value of information for investors. They al so state that the audit report for investors is not a part of the decision-making process. Lastly, studies show that auditor opinions do not have a significant effect on stock prices and returns. These differences can be caused by the time, country or the methods of the studies.

In general, when the literature is examined, no study was encountered that on how much institutional investors consider independent audit in investment decisions. Than, the views of managers of institutional investors including banks, brokerage houses, investment trusts and portfolio management companies registered with the Turkish Capital Association (TCA) have been consulted in order to determine whether the independent auditing practices and results are influential on the investment decisions of the institutional investor and if so, to determine the degree.

\section{A research to determine the effect of independent auditing on investment decisions of institutional investors}

In this section, the purpose and the importance of the research, the scope of the research, the method applied in the research, the hypotheses of the research, the analysis and findings of the research data are included.

\subsection{The purpose and the importance of the research}

The main purpose of the research is to determine whether the results of the independent auditing are effective for the investment decisions of the institutional investor and if so, to determine the degree. The brokerage house, which is one of the institutional investors, is to investigate perception differences related to independent auditing while it decides to invest among the portfolio management company, the investment partnership, and the bank. It is also the purpose of the research to develop recommendations in order to demonstrate the importance of independent auditing.

Institutional investors are required to research the results of independent audits in investment decisions, and to contribute to the literature by measuring and eval uating the effects of their applications. 


\subsection{The scope of the research}

As of October 2015, 228 institutional investors (banks, brokerage houses, investment trusts and portfolio management companies) registered in the Turkish Capital Association (TCA) constitute the scope of the research. 17 of the institutional investors were temporarily suspended. In this case, 211 institutional investors registered with TCA also constitute the main mass of the research at the same time The data source in the study is the managers in different positions. Questionnaires were sent via e-mail to the 211 institutional investors active in TCA, the main mass of the research. The names of the banks, brokerage houses, investment trusts and portfolio management companies and the tel ephone numbers, open addresses and / or electronic mail addresses of these companies were obtained from the internet addresses of the CMB and TCA and the internet addresses of the companies. By linking to a web page given in the email, companies are directed to the questionnaire; Answers are recorded in the same database. So they did not have to send e-mails to send their answers. In order to increase the response rate of the questionnaire, necessary correspondences were obtai ned from TCA. A total of 211 institutional investors registered with TCA were sent a questionnaire and 118 questionnaires were found suitable for analysis. In this case, the return rate is approximately $56 \%$.

\subsection{The method of the research}

Following the theoretical study in the research, the survey method was used as the method applied to measure the effect of independent auditing of institutional investors on investment decisions. Since there is no scale related to the research topic, the questions on the questionnaire were prepared by taking the literature survey results into consideration, especially by making use of Gomez-Guillamon (2003), Adeyemi and Uadiale (2011), Leung and Chau (2001), Best et al. (2001) and Fadzly and Ahmad (2004). The prepared questionnaire was completed in May 2015 after the examination of experts and a pi lot study on bank managers in Tokat.

The first section of the two-part questionnaire is a closed-end, 5-point Likert scale for determining how much institutional investors take into account independent control of investment decisions. There are 26 expressions in the first chapter. 1-7 expressions are related to Hypothesis 1, 8-15 expressions are 2. Hypothesis related, 16-21 expressions are related to 3. Hypothesis, and 22-26 expressions are related to the fourth hypothesis. In the second part, there are 9 questionnaires including demographic characteristics of participating institutional investors and participant information. In this case, the questionnaire consists of 26 expressions and 9 questions. Surveys are open on the internet from J une 1, 2015 to October 8, 2015. 


\subsection{F indings of the research}

The analysis of the study was first started with reliability analysis and the reliability of the questionnaire was measured. Then frequency analysis was done. To test the research hypotheses, a normality test was performed to determine whether to use parametric or nonparametric tests. Mann-Whitney $U$ test was applied to the hypotheses firstly after Kruskall Wallis test.

Research data were analyzed using SPSS (Statistical Package for the Social Sciences) and Microsoft Office Excel programs. Reliability analysis was done first. It is called reliability that reveals the consistency of all the questions in a measurement (test, questionnaire) with each other and the homogeneity in measuring the problem studied (Akgül \& Çevik, 2003: 434). The Cronbach al pha coefficient was used to measure the reliability of the questionnaire. The Cronbach Alpha Coefficient, which investigates whether the whole of the scal e in question is homogeneous in order to explain its homogeneity, shows the similarity and closeness of the questions in the cases where the individual scores are collected by the answers given to the questions. The ranges and the reliability of the scale where the Alfa coefficient can be found between 0 and 1 are as follows (Akgül \& Çevik, 2003: 435-436):

$$
\begin{aligned}
& \text { If } 0.00 \leq \alpha<0.40 \text {, the scal eis not reliable } \\
& \text { If } 0.40 \leq \alpha<0.60 \text {, the scale is low reliability. } \\
& \text { If } 0.60 \leq \alpha<0.80 \text {, the scal eis mostly reliable. } \\
& \text { If } 0.80 \leq \alpha<1.00 \text {, the scale is highly reliable. }
\end{aligned}
$$

The Cronbach Alpha coefficient obtained in the study is 0.928 . This figure indicates that the survey is highly reliable.

Then frequency distributions were given according to the characteristics of institutional investors who answered the questionnaire. Subsequently, brokerage house managers, investment partnership managers, portfolio management company managers and bank managers are presented with views on statements prepared according to the 5-point Likert scale.

It has been determined whether parametric or nonparametric tests should be applied to the research data by testing normal ity. The Shapi ro Wilks test should be used when the number of subjects is less than 29 in the normality test, and the Kolmogorov-Smirnov test should be used when the number of subjects is more than 29 (Akgül \& Çevik, 2003: 99). The results obtained from the normality test for the four hypothesis-related groups (Brokerage House (43), Investment Trust (24), Portfolio Management Company (21), Bank (30)) did not meet the normal distribution ( $p \varangle 0,05$ ). This resulted in the need to use non-parametric tests. 
In the test of research hypotheses, Kruskall Wallis test was used to compare nonparametric tests between three or more groups with continuous variables and then to show which group is different from the other group; Mann-Whitney $U$ test was used to test significant differences between two independent groups.

5.4.1. General characteristics of institutional investors participating in the research

$73.7 \%$ of the managers of institutional investors who responded to the survey were male and $26.3 \%$ were females. $73.3 \%$ of the institutional investor managers are in the age range of $20-40,26.7 \%$ are in the 40 and above $36.4 \%$ of the institutional investor managers work in the Brokerage House, $25.4 \%$ in the Bank, $20.3 \%$ in the Investment Trust and $17.8 \%$ in the Portfolio Management Company. $25.4 \%$ of institutional investor managers are experts, $23.7 \%$ are managers, $18.6 \%$ are portfolio managers, 9.3\% are managers, $8.5 \%$ are directors, $5.9 \%$ are board members, partners, general managers, Senior manager consisting of assistant general managers, $4.2 \%$ assistant manager, and lastly $4.2 \%$ seni or executive. $49.2 \%$ of institutional investor managers have between 1-10 years, 38.1\% between $11-20$ years and $12.7 \%$ more than 21 years. Institutional investor managers account for $60.2 \%$ of the bachelor's degree, $35.6 \%$ hold a master degree and $4.2 \%$ hold a doctorate degree.

5.4.2. Perceptions of institutional investors using independent audit in investment decisions

In this section, for the investment decisions of the institutional investors consisting of brokerage houses, investment partnerships, portfolio management companies and banks participating in the research; the information contained in the independent audit report of the company to be invested, the audit opi nion, whether the audit was carried out by 4 major audit firms, and the perceptions of the extent to which the independent audited financial statements are effective are presented.

In this part of the study, participants in the survey were asked to indicate whether they participated in the 5-point Likert scale and prepared statements to measure how much they considered independent control of investment decisions. The weighted average for each expression was cal culated by giving the weight from 1 to 5, with the answer "I do not Participate Totally" in the direction of the answers obtained and 1 to say "I ParticipateTotally".

5.4.3. Analysis of the differences among institutional investors' measures of using independent audit in investment decisions

In this part of the study, the existence of the differences in the application of independent auditing in investment decisions of brokerage houses, investment 
trusts, portfolio management companies and banks was examined. Here, the perception of the brokerage houses, investment partnerships, portfolio management companies and bank managers responding to the questionnaire are examined by matching. The findings of the statistical analyzes were reveal ed and the findings of the tested hypotheses are explained.

a) Analysis of the differences among institutional investors' perceptions of investment decisions using the information contained in the independent audit report

The perceptions of the brokerage houses participating in the survey, investment trusts, portfolio management companies and banks' perceptions regarding the investment decisions used in the independent audit report are given in Table 1.

Table 1. A verage percentage of institutional investors who participated in the research on their use of information in the independent audit report on investment decisions

\begin{tabular}{|c|c|c|c|c|}
\hline Information in the I ndependent A udit Report & 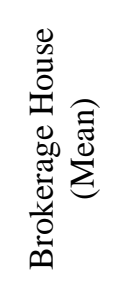 & 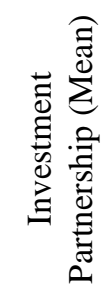 & 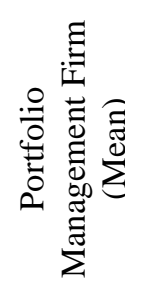 & 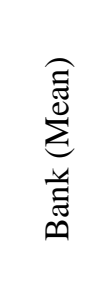 \\
\hline $\begin{array}{l}\text { 1. Independent audit reports are considered when } \\
\text { making investment decisions for a company. }\end{array}$ & 3.93 & 4.54 & 4.71 & 3.93 \\
\hline $\begin{array}{l}\text { 2. Independent audit reports are useful for estimating } \\
\text { company performance. }\end{array}$ & 3.83 & 4.41 & 4.09 & 3.86 \\
\hline $\begin{array}{l}\text { 3. Independent audit reports are effective in determining } \\
\text { the profitability (efficiency) of a company. }\end{array}$ & 3.81 & 3.95 & 3.90 & 3.80 \\
\hline $\begin{array}{l}\text { 4. I benefit from the independent audit report, while I } \\
\text { assess the future profitability of the new investments } \\
\text { of the company that I will invest in. }\end{array}$ & 3.53 & 3.91 & 3.80 & 3.86 \\
\hline $\begin{array}{l}\text { 5. I make use of the independent audit report when I } \\
\text { estimate the future cash flow volume or risk of the } \\
\text { company. }\end{array}$ & 3.62 & 4.04 & 3.76 & 3.96 \\
\hline $\begin{array}{l}\text { 6. An independent audit report may contain important } \\
\text { information about a firm's ability to sustain its } \\
\text { existence. }\end{array}$ & 3.83 & 4.29 & 3.85 & 3.90 \\
\hline $\begin{array}{l}\text { 7. The audit report is sufficiently useful and } \\
\text { understandable to make informed decisions. }\end{array}$ & 3.51 & 3.50 & 3.28 & 3.66 \\
\hline TOTAL & 3.72 & 4.09 & 3.91 & 3.85 \\
\hline
\end{tabular}


Research Hypothesis 1

$\mathrm{HO}$ : There is no statistically significant difference among perceptions of institutional investors regarding the effectiveness of the information contained in the independent audit report in investment decisions.

$\mathrm{H1}$ : There are statistically significant differences among the perceptions of institutional investors regarding the effectiveness of the information contained in the independent audit report in their investment decisions.

The 1 hypothesis is tested by cal culating a dimension of 7 words mentioned. With this dimension, participants' mean scores for 7 expressions are determined. Kruskall Wallis test was applied for the hypothesis and the results are given in Table 2 below.

Table 2. Results of the Kruskall W allis test on the use of the information contained in the independent audit report in the investment decisions of the institutional investors participating in the survey

\begin{tabular}{cccc}
\hline & $\begin{array}{c}\text { Chi- } \\
\text { square }\end{array}$ & $\begin{array}{c}\text { Degree of } \\
\text { Freedom }\end{array}$ & Significance \\
\hline $\begin{array}{c}\text { Information in the Independent Audit } \\
\text { Report }\end{array}$ & 0.889 & 3 & 0.828 \\
\hline
\end{tabular}

* Statistically significant at $10 \%$ significance level.

** Statistically signi ficant at $5 \%$ significance level.

*** Statistically significant at the $1 \%$ significance level.

According to the results of the Kruskall Wallis test, as shown in Table 2, there is no statistically significant difference among the perceptions of the broker managers, investment trust managers, portfolio managers and managers regarding the information contained in the independent audit report. In other words, the HO hypothesis has been accepted. Here, al though the average of brokerage managers is slightly lower than that of investment trust managers, portfolio management firms and bank managers, it does not make any statistical sense Here, institutional investors have stated that they use the information contained in the independent audit report on their investment decisions at the same level and use them in investment decisions.

b) Analysis of the differences among institutional investors' perceptions of taking the audit opinion type into consi deration in investment decision making

Averages for the perception of brokerage houses participating in the survey, investment trusts, portfolio management companies and banks to consi der the audit opinion type in investment decisions are given in Table 3. 
Table 3. A verage of Institutional Investors' Perceptions of Taking the A udit 0 pinion Type into C onsideration in Investment Decisions

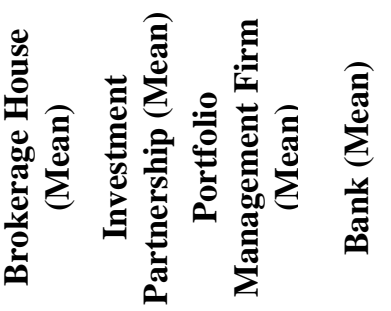

8. Thetype of audit opinion is influential on investment in a company.

$\begin{array}{llll}3.53 & 4.33 & 3.52 & 3.86 \\ 3.48 & 3.91 & 3.85 & 3.96 \\ 3.20 & 3.62 & 3.38 & 3.90 \\ 3.02 & 3.37 & 3.19 & 3.76 \\ 3.09 & 3.87 & 3.09 & 3.63 \\ 3.34 & 4.20 & 3.76 & 3.33 \\ 3.83 & 4.41 & 3.80 & 3.90 \\ 3.88 & 4.33 & 4.23 & 3.93 \\ 3.42 & 4.00 & 3.60 & 3.78\end{array}$

9. The information obtained by the auditor's opinion is useful when making investment decisions.

10. Thetype of audit opinion is influential in deciding the amount of investment.

11. Auditor's opinion has an impact on the company's share prices.

12. An independent audit report with a positive opinion is an indication of the investability of the operator.

13. The conditional audit opinion has a negative effect on the credibility of the investor.

14. An audit opi nion avoided from commenting has an adverse effect on the credibility of the investor.

15. Negative audit opinion has an effect on my investment decision.

Research Hypothesis 2

H0: There is no statistically significant difference among institutional investors' perceptions of the impact of audit opinion on investment decisions.

$\mathrm{H1}$ : There are statistically significant differences among the perceptions of institutional investors regarding the effectiveness of the audit opinion track in investment decisions.

The second hypothesis is tested by calculating a dimension of 8 words mentioned. With this dimension, participants' averages for 8 expressions between 8-15 are determined. The Kruskall Wall is test was applied for the hypothesis and the results are given in Table 4 below. 
Table 4. Results of the K ruskall W allis test for institutional investors participating in the study to consider the audit opinion type in investment decisions

\begin{tabular}{cccc}
\hline & Chi-Square & $\begin{array}{c}\text { Degree of } \\
\text { Freedom }\end{array}$ & Significance \\
\hline The Audit Opinion Type & 6.977 & 3 & $0.073^{*}$
\end{tabular}

* Statistically significant at $10 \%$ significance level.

** Statistically signi ficant at 5\% significance level.

*** Statistically significant at the $1 \%$ significance level.

As seen in Table 4, there is a statistical ly significant difference in the level of $10 \%$ significance among the perceptions of the broker managers, investment trust managers, portfolio managers, and bank managers on the information contained in the independent audit report, according to Kruskall-Wallis test results. In other words, the HO hypothesis has been rejected.

The Mann Whitney $U$ test was conducted to determine perception differences between the two specific groups. The Mann Whitney $U$ test was conducted between brokerage house managers, investment trust managers, portfolio management company executives and bank managers. The results of the Mann Whitney $\mathrm{U}$ test in general are shown in Table 5 below.

Table 5. Mann W hitney $U$ test results concerning the view of the audit opinion in investment decisions of institutional investors participating in the survey

A udit Opinion Type

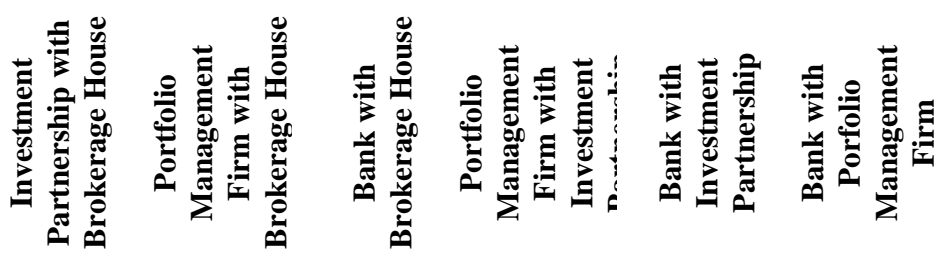

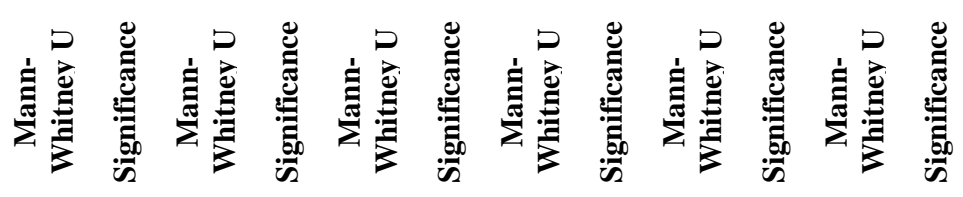

Consideration of audit opinion when managers makeinvestment decisions

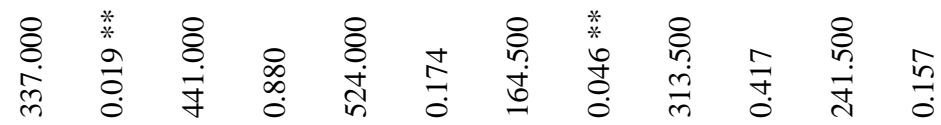

* Statistically significant at 10\% significance level.

** Statistically signi ficant at $5 \%$ significance leve.

*** Statistically significant at 1\% significance level. 
As shown in Table 5, the Mann Whitney $U$ test results for Hypothesis 2 are shown above. According to the Mann Whitney $U$ test results, there is a statistically significant difference in the level of 5\% significance between brokerage houses and investment management managers considering the audit opi nion type when making investment decisions.

Yet again, according to the Mann Whitney $U$ test results, there is a statistically significant difference in the level of $5 \%$ significance between investment partnership and portfolio management company managers' decision on audit review.

In this respect, it was concluded that there was a difference between the opi nions of the brokerage house, the investment partnership and the managers of the portfolio management companies regarding the view of the audit opinion when making investment decision. Here are the managers of investment partnerships; Portfolio management company executives, bank managers, and brokerage managers. The brokerage house managers are the ones that are least considered.

c) Analysis of the differences among the perceptions in investment decisions of the institutional investors related to the auditing by the 4 major audit firms

The averages for the perception of the brokerage houses participating in the survey, investment trusts, portfolio management companies and banks to be considered by the 4 maj or audit firms to audit the investment decisions are given in Table 6.

Table 6. A verage Percentage of the perceptions in investment decisions of the institutional investors related to the auditing by the 4 major audit firms

Auditing by the $4 \mathrm{M}$ ajor Audit Firms

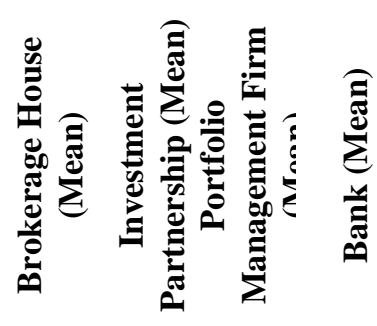

\begin{tabular}{|c|c|c|c|c|}
\hline $\begin{array}{l}\text { 16. When the investment decision is made, I check whether } \\
\text { the company is audited by the first } 4 \text { major audit companies. }\end{array}$ & 2.97 & 3.95 & 2.80 & 3.63 \\
\hline $\begin{array}{l}\text { 17. The fact that the company was audited by the first } 4 \text { major } \\
\text { audit companies while receiving an investment decision is } \\
\text { influential in the positive direction. }\end{array}$ & 3.30 & 4.16 & 2.80 & 3.83 \\
\hline $\begin{array}{l}\text { 18. I trust more in the financial statements of the audited firm } \\
\text { as the audits conducted by the first } 4 \text { major audit firms are of } \\
\text { better qual ity. }\end{array}$ & 3.20 & 4.00 & 3.04 & 3.63 \\
\hline $\begin{array}{l}\text { 19. Since the auditors of the first } 4 \text { major audit firms are better } \\
\text { at expertise and competence, they are influential in investing. }\end{array}$ & 3.25 & 4.00 & 2.33 & 3.40 \\
\hline
\end{tabular}




\begin{tabular}{|c|c|c|c|c|}
\hline Auditing by the $4 \mathrm{M}$ ajor Audit Firms & $\begin{array}{l}\frac{8}{8} \\
\frac{8}{1} \\
\frac{1}{9} \\
8 \\
\frac{8}{8} \\
\frac{8}{8} \\
\frac{8}{0} \\
\frac{10}{0}\end{array}$ & 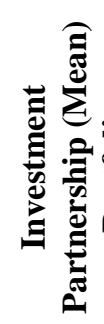 & 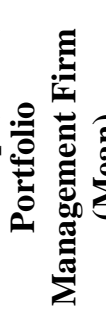 & 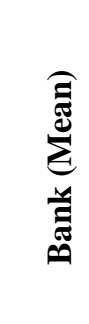 \\
\hline $\begin{array}{l}\text { 20. I only invest in companies audited by the first } 4 \text { major } \\
\text { audit firms. }\end{array}$ & 2.20 & 2.79 & 1.71 & 2.80 \\
\hline $\begin{array}{l}\text { 21. I think that the auditors of the first } 4 \text { major audit firms are } \\
\text { performing audit activities more effectively. }\end{array}$ & 3.06 & 3.95 & 3.19 & 3.33 \\
\hline TOTAL & 3.00 & 3.81 & 2.65 & 3.44 \\
\hline
\end{tabular}

Research Hypothesis 3

HO: There is no statistically significant difference between perceptions of institutional investors regarding the effectiveness of the audit by the 4 major audit firms.

$\mathrm{H1}$ : There are statistically significant differences between the perceptions of institutional investors about the effectiveness of the audit by the 4 major audit firms.

The 3th hypothesis is tested by calculating a dimension of the mentioned 6 expressions. This dimension determines the average of the participants' six expressions, 16-21. Kruskall Wallis test was applied for the hypothesis and the results are given in Table 7 below.

T able 7. K ruskall W allis test results regarding consideration of the audit by 4 big audit firms by institutional investors participating in the research for investment decisions

\begin{tabular}{cccc}
\hline & Chi-Square & $\begin{array}{c}\text { Degree of } \\
\text { Freedom }\end{array}$ & Significance \\
\hline Audit by 4 Big Audit Firms & 23.436 & 3 & $0.000 * * *$ \\
\hline
\end{tabular}

* Statistically significant at $10 \%$ significance level.

** Statistically signi ficant at $5 \%$ significance level.

*** Statistically significant at the $1 \%$ significanceleved.

As seen in Table 7, according to Kruskall-Wallis test results, there is a statistically significant difference in the level of significance among the perceptions of the broker managers, investment trust managers, portfolio managers and managers regarding the information contained in the independent audit report. In other words, the HO hypothesis has been rejected. 
The Mann Whitney $U$ test was conducted to determine perception differences between the two specific groups. The Mann Whitney $U$ test was conducted between brokerage house managers, investment trust managers, portfolio management company executives and bank managers. The results of the Mann Whitney $U$ test in general are shown in Table 8 below.

Table 8. M ann Whitney $U$ test results regarding consideration of the audit by 4 big audit firms by institutional investors participating in the research for investment decisions

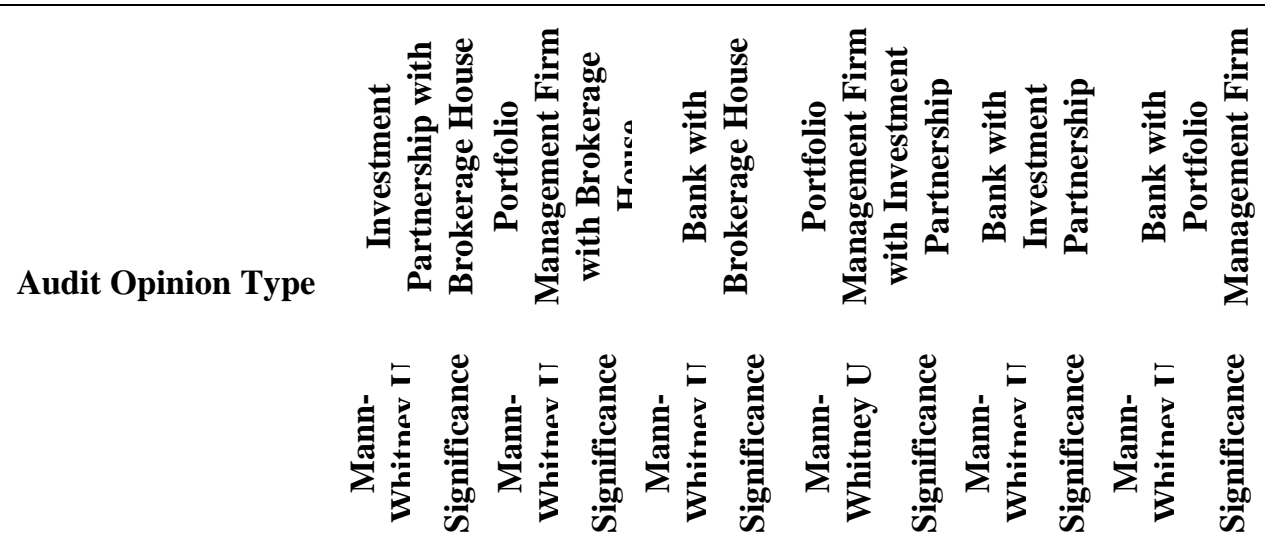

Consideration of audit opi inion when managers make investment decisions

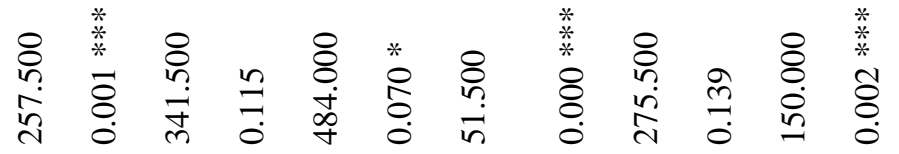

\footnotetext{
* Statistically significant at 10\% significance level.

** Statistically significant at $5 \%$ significance level.

*** Statistically significant at the $1 \%$ significancelevel.
}

The Mann Whitney $U$ test results for the 3rd hypothesis are shown above, as shown in Table 8. According to the Mann Whitney $U$ test results, there is a statistically significant difference at the $1 \%$ level of significance between brokerage houses and investment partners who consider investment decisions made by 4 major audit firms in charge of investment decisions.

According to the Mann Whitney $U$ test results, there is a statistically significant difference at the $10 \%$ leve of significance between brokerage firms and bank managers considering that they are made by 4 major supervisory firms that audit the investment decisions.

However, according to the Mann Whitney $U$ test results, there is a statistically significant difference in the level of significance of the investment partnership and portfolio management companies considering that they are being conducted by 4 maj or audit firms that audit the investment decisions. 
Finally, according to the Mann Whitney $U$ test results, there is a statistically significant difference between the portfolio management company and the bank managers at the $1 \%$ level of significance, considering that they are being conducted by 4 major audit firms that audit the investment decisions.

In this respect, it was concluded that there were differences between the opinions of the brokerage house, investment partnership, portfolio management company and bank managers regarding the decision of the 4 major audit firms to audit the company to invest while giving investment decision. Here, whereas the investment partnership managers stated that they consi dered that the investment decisions were made by four major audit firms, the managers of the portfolio management company stated that they have not considered.

d) Analysis of the Differences among the Perceptions of Institutional Investors on the use of Independent Audited Financial Statements in I nvestment Decisions

Table 9 summarizes the averages of the brokerage houses participating in the survey, investment trusts, portfolio management companies and banks' perception of their investment decisions using their independent audit financial statements.

T able 9. The averages of the institutional investors' perception of their investment decisions using the independent audited financial statements

Independent A udited F inancial Statements

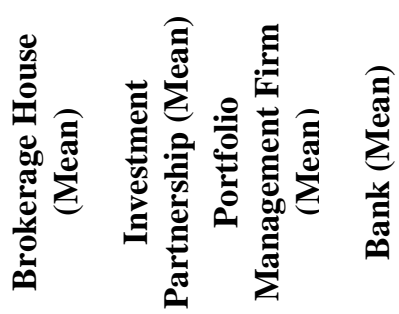

22. Independent audited financial statements provide an accurate and clear view for my investmentdecision.

$\begin{array}{llll}3.58 & 4.25 & 3.76 & 3.82\end{array}$

23. I use audited financial statements in monitoring the performance of the company.

$\begin{array}{llll}3.79 & 4.16 & 3.47 & 3.86\end{array}$

24. I rely on the audited financial statements for the investment decision.

$\begin{array}{llll}3.74 & 4.04 & 3.23 & 3.83\end{array}$

25. I trust in audited financial statements when

evaluating whether the company's assets have been managed well.

26. I use audited financial statements when I assess whether the assets of the company are well managed.

$3.62 \quad 3.95 \quad 3.00 \quad 3.80$

TOTAL

$\begin{array}{llll}3.58 & 3.87 & 3.47 & 3.80\end{array}$

\begin{tabular}{lllll}
3.66 & 4.05 & 3.39 & 3.82 \\
\hline
\end{tabular} 
Research Hypothesis 4

HO: There is no statistically significant difference between the perceptions of investment decisions of the institutional investors and the effect of the financial statements that were audited by independent audi tors.

H1: Institutional investors; There are statistically significant differences between the perceptions of the investment decisions and the effect of the independent audited financial statements.

The 4th hypothesis is tested by cal culating a dimension of 5 expressions mentioned here. With this dimension, participants' averages for 5 expressions between 22-26 are determined. Kruskall Wallis test was applied for the hypothesis and the results are given in Table 10 below.

T able 10. K ruskall W allis test results of the institutional investors' perception of their investment decisions using the independent audited financial statements

\begin{tabular}{lccc}
\hline & Chi-Square & $\begin{array}{c}\text { Degree of } \\
\text { F reedom }\end{array}$ & Significance \\
\hline $\begin{array}{c}\text { Independent A udited Financial } \\
\text { Statements }\end{array}$ & 2.707 & 3 & 0.439 \\
\hline $\begin{array}{l}* \text { Statistically significant at 10\% significance level. } \\
* * \text { Statistically significant at 5\% significance level. } \\
* * * \text { Statistically significant at the 1\% significanceleve. }\end{array}$ &
\end{tabular}

According to the results of Kruskall-Wallis test, as shown in Table 10, there is no statistical difference among the perceptions of brokerage managers, investment trust managers, portfolio management managers and bank managers regarding the use of independent financial statements in their investment decisions. In other words, the $\mathrm{HO}$ hypothesis has been accepted. Here, although the average of portfolio managers is slightly lower than that of investment trust managers, brokerage managers and bank managers, it is not statistically significant. However, institutional investors have stated that they use these statements in their investment decisions at almost the same level as statements about the use of independent financial statements in investment decisions. Only the portfolio management company directors use these tables in a cl ose proximity.

\section{Conclusion}

The fact that individual investors do not have sufficient knowledge accumulation and that there is a limited number of investment vehicles that they can invest because their savings are at a certain level are an obstacle to the dissemination of 
risk. Due to these and similar reasons, institutional investors who have the necessary technical equipment and sufficient expertise, follow the bazaars of the markets, take positions according to their developments and manage their portfolios in a professional manner have been formed. Institutional investors fulfill their functions by directing the large amount of funds they collect from individual investors to the capital market instruments through the professional ly manageable staff of the portfolio.

It is a very important issue for investors to reach accurate and reliable information in order to make the right decisions. The information they use must be relevant and reliable so that they can benefit significantly from the decisions they make In recent years, the growth of societies, the increase of economic activities and the increasing complexity of the economic life are decreasing the reliability level of the information presented. The need for relevant and reliable information has reveal ed the demand for accounting and auditing activities. Independent auditing, the period during which information about the economic activities and events of the company is collected in an unbiased manner to determine and report conformity with previously established and accepted criteria and to be communicated to the information users through a report of the evaluation and conclusion, enhances the reliability of information provided to investors, business owners, lenders and other related users. Independent auditing, which affirms the accuracy of certain financial statements, draws attention to the reliability of information provided by management.

In the direction of our research whose main aim is to determine whether the independent audit applications and results influence on the investment decisions of the institutional investors, according to the findings obtained as a result of the survey conducted to the institutional investors of the Turkish Capital Markets Association, brokerage managers, investment trust managers, portfolio management company managers and bank managers have stated that they have used this information in making investment decision by participating at the same level in the expressions related to the usage of the information in the audit report for investment decisions. Even if the institutional investors use the information contained in the independent audit report in their investment decisions, they were undecided on the positive side that the independent audit report was sufficiently useful and understandable.

According to the analysis results, investment partnership managers are more concerned about the audit opinion on investment decisions than portfolio managers, bank managers and brokerage managers. The managers of the brokerage houses are unstable in this respect. Nevertheless, it was the result that auditor opinions that were negative and refrained from commenting affected the investment decisions of institutional investors more than the positive and conditional audit opinions. In addition, while bank managers participated in the 
audit opinion that it had an impact on the company's share prices, others were unstable.

According to the analysis results, while the investment partnership managers state that for their investment decisions, they consider the audit by 4 big audit firms for the company that they will invest in, the portfolio management company managers states that they do not consider this. Brokerage house and bank managers have expressed an unstable situation in this regard. Only the investment trust managers are involved in thinking that the first four maj or audit firms are composed of more competent, more specialized inspectors and that their activities and results are more reliable.

According to the analysis results, the brokerage house managers, investment trust managers, portfolio management company managers and bank managers were attended at almost the same level of the expressions about the use of the independent audited financial statements in the investment decisions and they stated that they use these tables in investment decisions. Only the managers of the portfolio management companies have reveal ed a near-uncertainty in this matter. The brokerage house, investment partners and bank executives stated that they have confidence in the audited financial statements for the investment decision, while the managers of the portfolio management companies are unstable about trust.

As a result of the findings obtained, institutional investors, including brokerage houses, portfol io management companies, investment partnership and banks, which are included in the research, evaluate the investment decisions taking the information that may be useful for them in the audit report into consideration. When investing in a company, this information affects their attitudes. Although this is not the case at all, it is concluded that the independent audit report is indeed beneficial and useful, as well as affecting investment decisions. This demonstrates the independent and authentic assurance of institutional investors. The fact that the audit is conducted by four major audit firms, which is used as one of the quality criteria of audit in the literature, is not so important for institutional investors when making investment decisions. Finally, we can say that independent audit practices and results provide an information value to the institutional investor.

The result is while showing similarity to the results of the studies performed by Gomez-Guillamon (2003) and Salehi (2010); on the other hand differs with the results of the studies conducted by Anvarkhatibi et al. (2012) and Martinez et al. (2004). These differences can be caused by the time of the studies, countries or the methods applied.

This study has been analyzed in terms of the opinions of brokerage houses, investment trusts, portfolio management companies and bank managers registered 
in the Turkish Capital Association in Turkey. In future studies, researchers can create a larger sample, or can include other institutional investors in the sample It is al so possible to examine the extent to which individual investors use independent audit practices and results in their investment decisions.

\section{R eferences}

Adeyemi, S. B. \& Uadiale, O. M. (2011) "An empirical investigation of the audit expectation gap in Nigeria", African J ournal of Business Management, vol. 5(19): 7964-7971

Akgül, A. \& Çevik, O. (2003) İstatistiksel Analiz Teknikleri: SPSS'te Issletme Yönetimi Uygulamalar [Statistical Analysis Techniques: Management Applications in SPSS], Emek Ofset Ltd. Şti.,Ankara.

Akın, F. ve Ece, N. (2011) "Kurumsal yatırımcılar ve Türk sermaye piyasasında kurumsal yatırımcıların gelişimi üzerine bir değerlendirme [Institutional investors and an evaluation on the development of institutional investors in theTurkish capital market]", ABMYO Dergisi, vol. 22: 11-26

Anvarkhatibi, S., Safashur, M. \& Mohammadi, J. (2012) "The effect of auditors opinions on shares prices and returns in Tehran stock exchange", Research J ournal of Management Science, vol. 1(1): 23-27

Ataman, Ü., Hacirüstemoğlu, R. ve Bozkurt, N. (2001) Muhasebe Denetimi Uygulamalarl [Audit Practices], İstanbul: Alfa Yayınları.

Azibi, J., Tondeur, H. \& Rajhi, M. T. (2011) "Auditor choice and institutional investor characteristics after the enron scandal in the French context", International J ournal of Economics and Accounting, vol. 2(1): 32-52

Babuşcu, Ş. \& Hazar, A. (2007) Finansal Yönetim[Financial Management], SPK Lisanslama Serisi 16. Ankara: Akademi Consultin \& Training.

Best, P. J., Buckby, S. \& Tan, C. (2001) "Evidence of the audit expectation gap in Singapore", Managerial Auditing J ournal, vol. 16(3)134-144

Coşkun, A., Güner, M. F. \& Okudan, F. (2013) Denetim [Auditing], Kamu Gözetimi Muhasebe ve Denetim Standartları Kurumu Geçiş Dönemi Eğitimi Notları. İstanbul: Fatih Üniversitesi Sürekli Eğitim Merkezi.

Erdoğan, M. (2002) "Muhasebe, denetim ve bağımsız denetimin gerekliliği [Accouinting, auditing and the necessity of independent auditing]", Doğus Üniversitesi Dergisi, vol. 5: 51-63

Fadzly, M. N. \& Ahmad, Z. (2004) "Audit expectation gap", Managerial Auditing J ournal, vol. 19(7): 897 - 915

Gomez-Guillamon, A. D. (2003) "The usefulness of the audit report in investment and financing decisions", Managerial Auditing J ournal, vol. 18(6): 549-559

Güçlü, F. (2008) Muhasebe Denetimi: Illkeler ve Teknikler [Auditing: Principles and Techniques], Ankara: Detay Yayıncılık 
Harichandra, K. \& Thangavelu, S. M. (2004) "Institutional Investors, Financial Sector Development and Economic Growth in OECD Countries", National University of Singapore Department of Economics Working Paper, 0405.

Holt, T. P., \& DeZoort, T. (2009) "The effects of internal audit report disclosure on investor confidence and investment decisions", International Journal of Auditing, vol. 13(1): 61-77

Huyghebaert, N. \& Hulle, V. C. (2004) "The role of institutional investors in corporate finance", Tijdschrift voor Economie en Management, 49 (4): 689-726

Ittonen, K. (2012) "Market reactions to qualified audit reports: Research approaches", Accounting Research J ournal, vol. 25(1), 8-24

Kabajeh, M. A. M., Al Shanti, A. M., Dahmash, F. N. \& Hardan, A. S. ( 2012) "Informational content of auditor's report and its impact on making decisions from lenders and management's view in the jordanian industrial public firms", International J ournal of Humanities and Social Science, vol. 2(14): 93-103

Kaplan, S. E., Mowchan, M. \& Weisbrod, E. (2014) "Does Institutional Investor Behavior Influence the Market Reaction to Going Concem Audit Reports?", working paper

Kardeş-Selimoğlu, S., Özbirecikli, M., Uzay, Ş. Kurt, G., Alagöz, A. ve Yanık, S. (2011) Muhasebe Denetimi [Auditing], Ankara: Gazi Kitabevi

Lai, K. W. (2009) "Does audit quality matter more for firms with high investment opportunities?", J ournal of Accounting and Public Policy, vol. 28(1): 33-50

Leung, P. \& Chau, G. (2001) "The problematic relationship between audit reporting and audit expectations: Some evidence from Hong Kong", Advances in International Accounting, vol. 14: 181-200

Mansi, S. A., Maxwell, W. F. \& Miller, D. P. (2004) "Does auditor quality and tenure matter to investors? Evidence from the bond market", J ournal of Accounting Research, vol. 42(4): 755-793

Martínez, M. C. P., Martínez, A. V. \& Benau, M. A. G. (2004) "Reactions of the Spanish capital market to qualified audit reports", European Accounting Review, vol. 13(4): 689-711

Moradi, M. Sal ehi, M. Rigi, M., \& Moeinizade, M. (2011) "The effect of qualified audit report on share prices and returns: Evidence of Iran", African J ournal of Business Management, vol. 5(8): 3354-3360

Ogneva, M. \& Subramanyam, K. R. (2007) “Does the stock market underreact to going concern opinions? Evidence from the US and Australia", J ournal of Accounting and Economics, vol. 43(2): 439-452

Ruiz-Barbadillo, E., Gómez-Aguilar, N., De Fuentes-Barberá, C. \& García-Benau, M. A. (2004) "Audit quality and the going-concern decision-making process: Spanish evidence", European Accounting Review, vol. 13(4): 597-620

Salehi, M. (2010) “Evaluating effectiveness of external auditors' report: empirical evidence from Iran", Pakistan J ournal of Commerce and Social Sciences, vol. 4(1): 69-83 
Soltani, B. (2007) Auditing. An International Approach, Harlow: Prentice HallPearson Education.

Tahinakis, P. Mylonakis, J. \& Daskalopoulou, E. (2010) "An appraisal of the impact of audit qual ifications on firms' stock exchange price fluctuations", Enterprise Risk Management, vol. 2(1): 86-99

Usul, H. \& Kocabıyık, T. (2010) "Kurumsal yatırımcıların hisse senedi seçiminde göz önünde bulundurduğu etmenlerin faktör analiziyle incelenmesi: Türkiye örneği [Investigation by factor analysis of factors considered in the selection of stocks by instutional investors: The case of Turkey]", Süleyman Demire Üniversitesi İktisadi ve İdari Bilimler Fakültesi Dergisi, vol. 15(3): 63-78

Uzun, F. (2007) "İç denetim ve Fransa uygulaması [Internal auditing and France implementation]", Yerel Yönetimve DenetimDergisi, vo. 12(9), 1-11

Zor, İ. \& Aslanoğlu, S. (2005) "Kurumsal yatırımcı olarak özel emeklilik fonları: Türkiye' de oluşturulan sisteme yönelik değerlendirme ve geleceğe yönelik bir tahmin [Private pension funds as institutional investors: Evaluation of a system created in Turkey and a forecast for the future]", Muhasebe ve Finansman Dergisi, vol. 26: 184-197 